\title{
The Influence of Social Media About Covid-19 on Handwashing Behavior, Mask Wearing and Physical Distancing of Indonesian Students
}

\author{
Erika Martining Wardani*, Difran Nobel Bistara, Eppy Setiyowati \\ Faculty of Nursing and midwifery, Universitas Nahdlatul Ulama, Surabaya, Indonesia \\ *erika@unusa.ac.id
}

\begin{abstract}
Covid-19 is a phenomenal piece of information that is spread through social media and has become the center of attention all over the world and until now the virus is still spreading rapidly and is still a mystery. The data shows that $66 \%$ of exposed patients in Wuhan and WHO determined this case to be a pandemic case, Indonesia being the affected country, and there were 333,449 confirmed positive cases. Efforts to prevent the spread of covid-19 through social media by providing information about covid-19. The study aims to determine the effect of social media on covid19 on hand washing behavior, mask wearing and physical distancing among Indonesian students.

A pre-experimental research method with pre-test and post-test design. The research sample was 5400 students who were taken using simple random sampling technique. Health education interventions are given through social media and then the data is collected by distributing questionnaires with google form. Data were analyzed using the Wilcoxon test.

The results showed that after intervention through social media about covid-19 there was a change in transmission prevention behavior ( $\mathrm{p}$ value 0.046 ), hand washing behavior $(\mathrm{p}$ value 0.011), mask wearing ( $\mathrm{p}$ value 0.014), and physical distancing ( $\mathrm{p}$ value 0.000). Social media is effectively used to provide health education because it can increase student knowledge and influence behavior in preventing covid-19 transmission.
\end{abstract}

Keywords: Social Media, Behavior, Prevention, Covid-19 


\section{STRADA Jurnal Ilmiah Kesehatan}

DOI: $10.30994 /$ sjik.v9i2.459

ISSN: 2252-3847 (print); 2614-350X (online)

Vol.9 No.2 November 2020 Page.1338-1345

\section{BACKGROUND}

Information technology in the digital era which is currently developing rapidly brings a change in society. Social media is a primary need and has changed people's behavior patterns. Various groups and ages, almost all Indonesians use social media as a means of obtaining and conveying information to the public. Technological developments are indeed very necessary, every innovation is created to provide positive benefits for human life and provide new ways of doing activities (Nasution, 2017). Covid-19 is one information that is currently phenomenal because the virus spreads quickly and becomes mysterious, information that is disseminated through social media and has become the center of attention around the world.

Epidemiological data in Wuhan, Hubei Province, China (2019) showed 66\% of patients were exposed. In 2020, the beginning of new cases was also found in 28 countries and then spread rapidly to all parts of the world, so that the Covid-19 case became a pandemic (WHO, 2020). PHEOC data from the Ministry of Health of the Republic of Indonesia (2020) notes that Indonesia is one of the countries that is also exposed to the Covid-19 virus as evidenced by the finding of 333,449 positive confirmed cases in October 2020.

Social media is the most used media by humans today, including students. There are various types of social media and the most widely used by students are Instagram, Facebook, Twitter, WhatsApp, and Google.com. Social media has an important contribution because it makes it easier for students to exchange information and easily get online literature, this is a positive effect of social media while the negative effect is addiction, of course easily accessing information on social media causes changes in thinking and the behavior of the user in this case is the student. Social media can also be used as an online medium (facilitator) that strengthens the relationship between users as well as a social bond (Nasrullah, 2017).

Information during the coronavirus pandemic is how pathogens or viruses can spread, namely through contact with the environment or contaminated objects, close contact, respiratory droplets, and particles from airborne pathogens. Apart from the airbone, pathogen transmission can also enter through blood or other fluids from the human body that enter through the mucous membrane or exposed / injured skin (PDPI, 2020). This transmission can be prevented by washing hands with running water and soap, avoiding touching the mucosa both the eye, nose and mouth mucosa, avoiding contact with people who are sick, using masks, staying at home when the body is unwell or having an immediate check-up. going to a health service center, not doing activities outside the home, applying the correct cough / sneezing ethics (PDPI, 2020).

According to UB students who were declared cured, coronavirus can be prevented by following government protocols, maintaining health, maintaining cleanliness and nutritious food (Kompas, 2020). This he conveyed through social media.

Various interventions are carried out to prevent, treat and control the transmission of covid-19. Providing health information is important to do, besides that what is important is also the behavior of washing hands, mask wearing and physical fishing to cut the chain of transmission of this virus. Researchers assume that social media about Covid-19 can increase good behavior to prevent Covid-19 transmission. 


\section{STRADA Jurnal Ilmiah Kesehatan}

DOI: $10.30994 /$ sjik.v9i2.459

ISSN: 2252-3847 (print); 2614-350X (online)

Vol.9 No.2 November 2020 Page.1338-1345

\section{METHODS}

The study used a pre-experimental design method, the design used was pre and post test research. The population used is all students in the territory of Indonesia who come from 2136 tertiary institutions (Dikti Kemendikbud, 2020).

This research uses simple random sampling technique. The number obtained in this study was 5400 respondents. Data collection using tools in the form of a questionnaire with google form distributed to respondents both before and after the intervention in the form of providing health education about Covid-19 through social media. The data were not normally distributed, so the data analysis used an alternative test, namely the Wilcoxon test with a $\mathrm{p}$ value of $0.000(<0.005)$. This research has passed the ethical clearance no 164 / EC / KEPK / UNUSA / 2020.

\section{RESULT}

1) Univariate analysis

Table 1 Demographic Characteristics in Indonesian students

\begin{tabular}{|c|c|c|c|}
\hline No & Variable & Frequency $(n=5400)$ & Percentage $(\%)$ \\
\hline \multicolumn{4}{|c|}{ 1. Gender } \\
\hline & Male & 2480 & 45,9 \\
\hline & Female & 2920 & 54,1 \\
\hline \multicolumn{4}{|c|}{ 2. Age range } \\
\hline & $18-22$ years old & 3650 & 67,6 \\
\hline & More than 23 years old & 1750 & 32,4 \\
\hline \multicolumn{4}{|c|}{ 3. Level of education } \\
\hline & D1/D2 & 178 & 3,3 \\
\hline & D3 & 1577 & 29,2 \\
\hline & DIV/S1 & 3321 & 61,5 \\
\hline & $\mathrm{S} 2$ & 261 & 4,8 \\
\hline & S3 & 63 & 1,2 \\
\hline \multicolumn{4}{|c|}{ 4. The area of residence } \\
\hline & Western of Indonesia & 2841 & 52,6 \\
\hline & Center of Indonesia & 1546 & 28,6 \\
\hline & East of Indonesia & 1013 & 18,8 \\
\hline
\end{tabular}

Table 1 shows that the majority of demographic data based on gender are 54\% women, almost half of them are aged 18-22 years 67.6\%, most of these students are currently studying DIV / S1 61.5\% with residence mostly in western of Indonesia (52.6\%).

2) Bivariate analysis

a) The influence of social media about covid-19 on prevention behavior of covid-19 transmission

Table 2 The influence of social media on covid-19 on prevention behavior of covid-19 transmission among students in Indonesia $(n=5400)$

\begin{tabular}{lccccccc}
\hline \multirow{2}{*}{ Groups } & \multirow{2}{*}{$\mathrm{n}^{*}$} & \multicolumn{2}{c}{ Before intervention } & \multirow{2}{*}{$p$ value } & \multicolumn{2}{c}{ After intervention } & \multirow{2}{*}{$p$ value } \\
\cline { 3 - 4 } \cline { 6 - 7 } & & Mean & SD & & Mean & SD & \\
\hline Intervention & 1800 & 93,33 & 13,169 & 0,107 & 94,63 & 11,293 & 0,046 \\
Control & 3600 & 93,53 & 12,232 & & 93,73 & 10,232 & \\
\hline
\end{tabular}




\section{STRADA Jurnal Ilmiah Kesehatan}

DOI: $10.30994 /$ sjik.v9i2.459

ISSN: 2252-3847 (print); 2614-350X (online)

Vol.9 No.2 November 2020 Page.1338-1345

Table 2 shows that there is an influence on social media about covid-19. The Wilcoxon test results obtained $\mathrm{p}$ value 0.046 ( $\mathrm{p}<0.05$ ), then $\mathrm{Ha}$ is accepted, which means that there is a significant influence on the behavior of prevention of Covid-19 transmission before and after health education is given through social media.

b) The influence of social media on covid-19 on hand washing behavior

Table 3 The influence of social media on covid-19 on hand washing behavior among students in Indonesia $(\mathrm{n}=5400)$

\begin{tabular}{lccccccc}
\hline \multirow{2}{*}{ Groups } & \multirow{2}{*}{$\mathrm{n}^{*}$} & \multicolumn{2}{c}{ Before intervention } & \multirow{2}{*}{$p$ value } & \multicolumn{2}{c}{ After intervention } & \multirow{2}{*}{$p$ value } \\
\cline { 3 - 4 } \cline { 7 - 8 } & & Mean & SD & & Mean & SD & \\
\hline Intervention & 1800 & 18,28 & 2,483 & 0,059 & 19,13 & 1,332 & 0,011 \\
Control & 3600 & 18,22 & 2,572 & & 18,92 & 1,249 & \\
\hline
\end{tabular}

Based on table 3, it can be seen that there is an influence on social media about covid-19. The Wilcoxon test results obtained p value 0.011 ( $\mathrm{p}<0.05$ ), then Ha is accepted, meaning that there is a significant effect on the behavior of washing hands before and after being given health education through social media.

c) The influence of social media about covid-19 on the behavior of mask wearing

Table 4 The influence of social media on covid-19 on the behavior of mask wearing among students in Indonesia $(\mathrm{n}=5400)$

\begin{tabular}{lccccccc}
\hline \multirow{2}{*}{ Groups } & \multirow{2}{*}{$\mathrm{n}^{*}$} & \multicolumn{3}{c}{ Before intervention } & \multirow{2}{*}{$p$ value } & \multicolumn{3}{c}{ After intervention } & \multirow{2}{*}{$p$ value } \\
\cline { 3 - 4 } \cline { 6 - 7 } & & Mean & SD & & Mean & SD & \\
\hline Intervention & 1800 & 32,50 & 4,933 & 0,067 & 33,00 & 14,278 & 0,014 \\
Control & 3600 & 33,21 & 4,958 & & 32,82 & 12,13 & \\
\hline
\end{tabular}

Table 4 shows that there is an influence on social media about covid-19. The Wilcoxon test results obtained p value 0.014 ( $\mathrm{p}<0.05$ ), so there is a significant influence on the behavior of mask wearing before and after being given health education through social media.

d) The influence of social media about Covid-19 on physical distancing behavior

Table 5 The influence of social media on covid-19 on physical distancing behavior among students in Indonesia $(\mathrm{n}=5400)$

\begin{tabular}{|c|c|c|c|c|c|c|c|}
\hline \multirow{2}{*}{ Groups } & \multirow{2}{*}{$\mathrm{n}^{*}$} & \multicolumn{2}{|c|}{ Before intervention } & \multirow{2}{*}{$p$ value } & \multicolumn{2}{|c|}{ After intervention } & \multirow[t]{2}{*}{$p$ value } \\
\hline & & Mean & $\mathrm{SD}$ & & Mean & SD & \\
\hline Intervent & 1800 & 42,56 & 6,480 & 0,083 & 42,50 & 6,436 & 0,000 \\
\hline Control & 3600 & 42,76 & 6,751 & & 42,22 & 6,241 & \\
\hline
\end{tabular}

Table 5 shows that there is an influence on social media about covid-19. The Wilcoxon test results obtained $\mathrm{p}$ value $0.000(\mathrm{p}<0.05)$, which means that there is a significant influence on physical distancing behavior before and after health education is given through social media. 


\section{STRADA Jurnal Ilmiah Kesehatan}

DOI: $10.30994 /$ sjik.v9i2.459

ISSN: 2252-3847 (print); 2614-350X (online)

Vol.9 No.2 November 2020 Page.1338-1345

\section{DISCUSSION}

1. Characteristics of Indonesian students

a. Gender and ages

Based on the research results, it was found that the majority of female students (54\%) used social media more than students. Almost half are aged 18-22 years, $67.6 \%$, this data shows that the use of social media is the same between students and female students.

This is in line with Soliha's (2015) study, where the majority of social media users in the study were female (56\%) while male (44\%), age range $21-23$ years $(54 \%)$. There was no difference in the level of dependence on social media consumption patterns between male and female.

Social media is a major need for students because with social media they get updated and complete information including about Covid-19.

b. Level of education

The results showed that the majority of respondents are currently studying DIV / S1 61.5\%. Respondents use social media to find information while those who are currently studying are used to make it easier to do assignments given by the lecturer.

Based on the level of education, infographic data on internet user penetration shows that $79.23 \%$ comes from S1 / Diploma (APJII, 2017).

This is in line with Drakel's research, et al (2018), which stated that the social media commonly used by students, namely Google.com and Whatsapp, because both are easy to use and help when doing assignments because they are fast operating, just search and click immediately what appears searching for.

Social media is the main need for students because all information is available in it and easy to access anywhere and anytime. For DIV / S1 students, the final semester is widely used to search for literature in thesis preparation.

c. The area of residence

The results showed that most students lived in western Indonesia (52.6\%). This is because most universities are in Java such as UI, UGM, Unpad, Unair, ITS, and many more so that they have more access from where students live. According to a survey conducted by Kominfo (2017), it shows that the highest internet usage is in Java $(87.7 \%)$, Sumatra $(84.37 \%)$, Kalimantan $(81.17)$, where the three places are included in Western Indonesia.

2. The influence of social media about covid-19 on prevention behavior of covid-19 transmission

The results showed that there was an influence of social media about covid-19 on the behavior of prevention of covid-19 transmission with a p value of 0.046 . This is in line with research conducted in Uganda by Ssebuufu, et al., (2020), good knowledge and behavior will influence each other, it is also the same as research in China which shows the results if someone has good knowledge then has behavior for prevention. Covid-19 (Peng, et al., 2020).

Proper health education is an effort that can be done to improve the readiness of the community, including students, to face situations during the pandemic because it will affect knowledge, perceptions, attitudes and behavior. Increased knowledge will shape the perception of an individual to be positive, this can encourage a good attitude so that someone is able to behave appropriately (Peng, et al., 2020).

Education carried out by the government through social media about health protocols that must be carried out by the community when meeting other people, such 


\section{STRADA Jurnal Ilmiah Kesehatan}

DOI: $10.30994 /$ sjik.v9i2.459

ISSN: 2252-3847 (print); 2614-350X (online)

Vol.9 No.2 November 2020 Page.1338-1345

as always using a medical mask, maintaining a minimum distance of 1 meter, and washing hands properly and properly using water and soap (Mas'udi \& Winanti, 2020).

The role of all stake holders by providing health education about preventing the spread of covid through social media is important to do continuously so that students can easily access and with accurate information is able to change student behavior to implement healthy behavior by breaking the chain of covid-19 distribution according to the protocol. health that has been recommended by the government either by washing hands, wearing mask and physical distancing.

3. The influence of social media on covid-19 on hand washing behavior

The research that has been conducted shows that there is an influence between social media about Covid-19 on hand washing behavior ( $p$ value 0.011). Research that is in line with research by Rina (2015) which proves that there is an effect of health education on hand washing on student compliance who practices in the ICU, students tend to obey in doing Five Moment after being given health education.

Social media is the most effective media in providing health education related to how to wash hands properly, namely using soap and running water or using a hand sanitizer for 20 seconds with the right steps that must be taken to break the chain of spread of covid-19 because it is in the hands of many microorganisms, both bacteria. and viruses that are not visible to the naked eye, where the hand is one of the places where the virus spreads when someone coughs / sneezes or shakes hands.

4. The influence of social media about covid-19 on the behavior of mask wearing.

The results showed that there was an effect of social media on covid-19 with the use of masks ( $p$ value 0.014). This is in accordance with the research of Rustika and Burase (2018), with the results obtained for $\mathrm{P}<0.05$ which means that there is a relationship between the behavior of not using masks and the incidence of ARI and the OR results obtained are 5.460, meaning that by not wearing mask, there is a 5 times more risk of being exposed to it. ARI compared to mask wearing.

Covid-19 transmission through the air that has been exposed to the corona virus and attacks the respiratory tract of the human body. One of the absolute precautions students take is to mask wearing.

5. The influence of social media about Covid-19 on physical distancing behavior

Research shows that there is an effect of social media about covid-19 on physical distancing behavior ( $p$ value 0.000). This research is in accordance with research in 2020 by Syadidurrahmah, et al, which shows that gender, knowledge is related to the physical distancing of UIN Syarif Hidayatullah Jakarta students, where physical distancing behavior (55.9\%) and women (63.1\%) apply physical distancing. Female students are 3.4 times more likely to apply physical distancing behavior than students.

Based on the research results, it was found that the majority of female students (54\%) used social media more than students. Women tend to want to get a lot of information from social media. This can happen because women tend to be more aware of health by maintaining nutrition, feeling healthy, relaxing, resting, and men prioritizing not being sick (Layli, et al, 2020).

Providing health information through social media if done with continuous time about the transmission of covid-19 will provide knowledge to students to limit or keep their distance from other people by limiting the distance to less than 1 meter so that students are expected to be able to implement behavioral prevention behaviors of Covid-19 transmission so that Covid-19 transmission can be prevented. 


\section{STRADA Jurnal Ilmiah Kesehatan}

DOI: $10.30994 /$ sjik.v9i2.459

ISSN: 2252-3847 (print); 2614-350X (online)

Vol.9 No.2 November 2020 Page.1338-1345

\section{CONCLUSION}

There were the influence of social media about covid-19 on hand washing behavior, mask wearing and physical distancing among students in Indonesia. Social media, which is widely used by students, has the effect of increasing knowledge about the prevention of covid-19 transmission by implementing behaviors according to health protocols such as washing hands with soap, mask wearing and physical distancing. Providing health education through social media is effective in providing knowledge so that it has an impact on good behavior in preventing the spread of covid-19.

\section{REFERENCES}

Asosiasi Pengguna Jasa Internet Indonesia/APJII. (2018). Data Statistik Pengguna Internet Indonesia 2018.

Huang C, Wang Y, Li X, Ren L, Zhao J, Zang Li, Fan G, etc. Clinical features of patients infected with 2019 novel coronavirus in Wuhan, China. The Lancet. 24 Jan 2020.

Januarti, D. W., Pratiknjo, M. H., \& Mulianti, T. (2018). Perilaku Mahasiswa Dalam Menggunakan Media Sosial di Universitas Sam Ratulangi Manado. Journal Unair, $21,1-20$.

Kasih. (2020). Pesan Mahasiswa Brawijaya yang Sembuh dari Covid-19: Corona Bukan Aib. https://edukasi.kompas. com/read/2020/04/02/114558871. Diakses tanggal 02 April 2020.

Kemenkes RI. Info Infeksi Emerging Kementerian Kesehatan RI [Internet]. Media Informasi Resmi Terkini Penyakit Infeksi Emerging Kementerian Kesehatan RI. 2020 [cited 2020 May 26]. Available from: https://covid19.kemkes.go.id/.

Kominfo. (2017). Survey penggunaan TIK Serta Implikasinya terhadap Aspek Sosial Budaya Masyarakat. Kementerian Komunikasi dan Informatika Republik Indonesia.

Layli FM, Adi MS, Saraswati LD, Ginandjar P. Gambaran Faktor - Faktor Kepatuhan Minum Obat dalam Pelaksanaan POPM di Kabupaten Semarang (Studi di WIlayah Kerja Puskesmas Gedangan Kecamatan Tuntang). J Kesehat Masy. 2020;8(2):16574.

Mas'udi, W. \& Winanti, P. S. (2020). Tata Kelola Penanganan Covid 19 di Indonesia. In: s.l.:Fakultas Ilmu Sosial dan Ilmu Politik Universitas Gajah Mada.

Nasrullah, R. (2017). Media Sosial: Perspektif Komunikasi, Budaya dan Sosioteknologi, Jakarta: Simbiosa Rekatama Media.

Nasution, M. S. A., Daulay, M. N. H., dan Susanti, N. 2017. Ilmu Sosial Budaya Dasar. Jakarta: PT RajaGrafindo Persada.

PDPI. (2020). Pneumonia covid-19. Diagnosa dan penatalaksanaan di Indonesia. Jakarta :PDPI.

Peng, Y. et al. (2020). Knowledge, Attitude and Practice Associated with COVID-19 among. Research square.

Putra, P. W. K., Kusuma Raharjo, A. A., \& Ngurah Darmawan, A. K. (2017). Pengaruh Pendidikan Kesehatan dengan Media Leaflet Terhadap Perilaku Mencuci Tangan Pengunjung di Rumah Sakit Umum Bali Royal. Journal Center of Research Publication in Midwifery and Nursing, 1(2), 45-54. https://doi.org/10.36474/caring.v1i2.6

Rina, Murdayaningsih. (2015), Pengaruh Pendidikan Kesehatan Cuci Tangan Terhadap Keaptuhan Mahasiswa Praktek Di Ruanga ICU RSUD Dr. Moewardi. Skripsi Stikes Kusuma Husada Surakarta. 


\section{STRADA Jurnal Ilmiah Kesehatan}

DOI: $10.30994 /$ sjik.v9i2.459

ISSN: 2252-3847 (print); 2614-350X (online)

Vol.9 No.2 November 2020 Page.1338-1345

Ssebuufu, R. et al. (2020). Awareness, knowledge, attitude and practice towards measures for prevention of the spread of COVID-19 in the Ugandans: A nationwide online cross-sectional Survey. medRxiv.

Soliha, S. F. (2015). Tingkat Ketergantungan Pengguna Media Sosial Dan Kecemasan Sosial. Tingkat Ketergantungan Pengguna Media Sosial Dan Kecemasan Sosial, 4(1), 1-10.https://doi.org/10.14710/interaksi.4.1. 1-10

Syadidurrahmah et al. Perilaku dan Promosi Kesehatan: Indonesian Journal of Health Promotion and Behavior. 2020; 2(1): 29-37.

Syadidurrahmah, F., Muntahaya, F., Islamiyah, S. Z., \& Fitriani, T. A. (2020). Perilaku physical distancing mahasiswa UIN Syarif Hidayatullah Jakarta pada masa pandemi covid-19. Jurnal Perilaku Dan Promosi Kesehatan, 2(1), 29-37.

WHO. Coronavirus disease (COVID-2019): Situation Report [Internet]. World Health Organization. $2020 . \quad$ Available from:https://www.who.int/emergencies/diseases/novel-coronavirus-2019/ situationreports. 